\title{
Cell death during luteal regression in the marmoset monkey (Callithrix jacchus)
}

\author{
F. M. Young ${ }^{1}$, P. J. Illingworth ${ }^{1 *}$, S. F. Lunn ${ }^{1}$, D. J. Harrison ${ }^{2}$ and \\ H. M. Fraser ${ }^{1}$ \\ ${ }^{1}$ MRC Reproductive Biology Unit, Centre for Reproductive Biology, 37 Chalmers Street, \\ Edinburgh EH3 9EW, UK; and ${ }^{2}$ Department of Pathology, University Medical School, Teviot Place, \\ Edinburgh EH8 9AG, UK
}

\begin{abstract}
The mechanism controlling luteal regression in primates is unknown but may involve cell death by apoptosis. Marmoset ovaries containing corpora lutea were studied at different stages of the normal ovarian cycle. Two additional groups of animals underwent induced luteolysis with either the prostaglandin $\mathrm{F}_{z a}$ analogue, cloprostenol, or the $\mathrm{GnRH}$ antagonist, antarelix, at the mid-luteal phase. Apoptosis in ovarian sections was estimated both by counting the number of cells exhibiting morphological features of apoptosis and by in situ labelling the $3^{\prime}$ ends of the DNA fragments with digoxigenin-11-dUTP. Apoptosis was found to be significantly increased in corpora lutea in the early follicular phase (equivalent to the later stage of luteal lifespan) compared with the mid-luteal phase corpora lutea, as judged by either computerized morphometry or $3^{\prime}$ end labelling. Apoptosis was also increased by the administration of either cloprostenol or antarelix when using the $3^{\prime}$ end labelling end point, but only after cloprostenol when using computerized morphometry. A further form of cell death, characterized by the formation of cytoplasmic vacuoles, was also observed in corpora lutea undergoing both induced and spontaneous regression. These results demonstrate that apoptosis within the primate corpus luteum is increased in both physiological and induced luteal regression. In addition, they show that an alternative form of cell death is involved in both spontaneous and induced luteal regression, although the relative importance of the two mechanisms remains to be determined.
\end{abstract}

\section{Introduction}

Luteal regression is characterized by decreasing steroid hormone production and a reduction in luteal mass; however, the exact mechanisms controlling structural and functional regression in primates are not fully understood. Although steroid hormone production in the primate corpus luteum is dependent on continuing LH secretion (Fraser et al., 1986), the decrease in steroid hormone production associated with physiological luteal regression is not associated with any apparent changes in either serum LH concentrations or pulse frequency (Hutchison and Zeleznik, 1986). While prostaglandin $\mathrm{F}_{2 a}$ from the uterus is the luteolytic signal in ruminants, after hysterectomy, primates have normal ovarian cycles and undergo regular luteal regression, indicating that the uterus is not the source of a luteolytic signal in these species. Therefore, it is likely that an intraovarian mechanism is important in controlling luteal regression in primates.

It is possible that apoptosis, an intracellular genetic programme resulting in cell death (Bellamy et al., 1995), is an

*Present address: Department of Obstetrics and Gynaecology, Westmead Hospital, Westmead, NSW 2145, Australia.

Received 10 February 1997. important pathway in primate luteal regression. Apoptosis has been demonstrated in the regressing corpus luteum of rabbits (Dharmarajan et al., 1994), rats (Orlicky et al., 1992), sheep (O'Shea et al., 1977; Sawyer et al., 1990; Kenny et al., 1994) and cows (Juengel et al., 1993; Zheng et al., 1994; Rueda et al., 1995).

Evidence of apoptosis can be sought by demonstration of either the specific morphological appearances of apoptosis or by a characteristic DNA fragmentation pattern (Wyllie 1980). The first visible morphological features of apoptosis are cytoplasmic and nuclear condensation accompanied by loss of microvilli and cell-cell junctions, and the formation of cell surface convolutions. Chromatin condenses into crescentshaped aggregates lining the nuclear membrane before the cell fragments into membrane bound apoptotic bodies which are removed from intercellular spaces through phagocytosis by neighbouring or immune system cells, or by being shed into the lumen of the gut or capillaries of the vasculature (Kerr et al., 1972; Wyllie and Morris, 1982; Morris et al., 1984; Schwartzman and Cidlowski, 1993). The generation of $185 \mathrm{bp}$ DNA fragments by specific endonucleases is a characteristic feature of apoptosis. These fragments can be visualized in situ by labelling $3^{\prime}$ ends of the DNA fragments with digoxigenin-11-UTP (Gavrielli et al., 1992). 
The purpose of the present study was to determine whether apoptosis is associated with regression in the corpus luteum of a non-human primate, the marmoset monkey. Two different methods were used to quantify and localize apoptosis and to relate this to overall luteal cellular morphology and function. In marmosets, luteal regression can be induced by treatment with either prostaglandin $\mathrm{F}_{2 \alpha}$ or a $\mathrm{GnRH}$ antagonist. Thus, this species represents a suitable model for studies on the cellular mechanisms involved in luteolysis induced by either of these pathways.

Since maintenance of luteal function is essential for the continuation of pregnancy, enhanced understanding of the luteolytic mechanism may lead to development of agents for fertility control in humans, which have a luteal site of action.

\section{Materials and Methods}

\section{Animals and treatments}

Female marmoset monkeys (Callithrix jacchus jacchus) were housed at the MRC Reproductive Biology Unit Primate Centre, as described by Hearn et al. (1975). All procedures were in accordance with the Animals (Scientific Procedures) Act 1986. Blood samples were collected on alternate days by femoral venepuncture, centrifuged for $20 \mathrm{~min}$ at $1000 \mathrm{~g}$ and the separated plasma was stored at $-20^{\circ} \mathrm{C}$ until required for progesterone assay. Ovarian cycles were monitored by measuring the plasma progesterone concentration as described by Smith ef al. (1990). The follicular phase was defined as that period during which progesterone concentrations were $\leq 12 \mathrm{nmol} \mathrm{l}^{-1}$. Day 1 of the luteal phase was assumed to be the day on which the progesterone concentration rose above $32 \mathrm{nmol} \mathrm{l}^{-1}$ and was followed by a sustained increase.

Naturally occurring luteal regression. Whole ovaries were collected from marmosets in the mid-luteal phase (day 10 , $n=4$ ), and the late luteal phase (day 18, $n=3$ ). Since luteal regression continues into the follicular phase of the subsequent ovarian cycle, ovaries were also collected in the early follicular phase (equivalent to days 20-24 of the luteal phase of the preceding cycle: $n=3$ ) and in the late follicular phase (equivalent to days 25-28 of the luteal phase of the preceding cycle; $n=3$ ). Therefore, these late 'luteal phase' ovaries have been classified below as being either early or late follicular phase.

Induced luteal regression. A group of marmosets was treated on day 9 of the luteal phase with either $1 \mathrm{mg} \mathrm{kg}^{-1}$ s.c. of the GnRH antagonist, antarelix (kindly donated by R. Deghenghi, Europeptides, Argenteuil; $n=4$; Hodges et al., 1988; Deghenghi et al., 1993), or $1 \mu \mathrm{g}$ i.m. of a prostaglandin $\mathrm{F}_{2 a}$ analogue, cloprostenol (Planate, Coopers Animal Health Ltd, Crewe, Cheshire; $n=4$; Summers et al., 1985; Fraser et al., 1995). Ovaries were collected $24 \mathrm{~h}$ later on day 10 of the luteal phase. The corpora lutea from these ovaries were studied in parallel with those obtained from the untreated animals on day 10 of the luteal phase.

\section{Tissue collection and preparation}

Animals were sedated with $100 \mu$ l ketamine hydrochloride (Parke-Davis Veterinary, Pontypool) i.m. and killed with
$400 \mu$ Euthatal i.v. (sodium pentobarbitone, Rhône Mérieux, Harlow). A terminal blood sample was taken before removing ovaries and tissues used in other studies. Ovaries were fixed in $4 \%(\mathrm{w} / \mathrm{v})$ buffered paraformaldehyde for $24 \mathrm{~h}$ before embedding in paraffin wax according to standard procedures. Sections $(4 \mu \mathrm{m})$ were mounted on slides coated with $50 \mu \mathrm{g}$ poly-t-lysine $\mathrm{I}^{-1}$ and either stained with haematoxylin and eosin or studied with $3^{\prime}$ end labelling as described below. In representative instances, ovaries were bisected through the corpora lutea and one half was embedded in OCT (Bayer Diagnostics, Basingstoke) in liquid nitrogen. Subsequently, $6 \mu \mathrm{m}$ sections were cut using a cryostat (2800 Frigocut; Reichert-Jung, Cambridge Instruments, Milton Keynes) before being thaw mounted onto slides. Slide-mounted sections were stored at $-70^{\circ} \mathrm{C}$ before staining with Oil Red $\mathrm{O}$.

\section{Morphometric analysis}

Paraformaldehyde fixed sections were rehydrated and stained with haematoxylin and eosin using standard procedures and then subjected to computerized morphometric analysis using a highly optimized microscope environment (HOME: Brugal et al., 1992). By this method, a computer-generated overlay is superimposed on the optical field image; the computer programme counts the cells fulfilling the morphological criteria defined below and records their exact location. This information was later retrieved and the identification of the cells confirmed by a second observer.

The number of $10000 \mu \mathrm{m}^{2}$ sections that needed to be assessed was counted by scoring a number of squares from different areas of the luteal tissue for four different animals (mid-luteal phase, early follicular, and after either antarelix or cloprostenol treatments). The numbers of each cell type found in successive $10000 \mu^{2}$ squares were added to the numbers from the previous fields and a series of cumulative mean values was generated. It was found that the estimate of mean numbers of each cell type present stabilized after examining four $10000 \mu \mathrm{m}^{2}$ fields and that the counting of further squares did not significantly change the values observed. Therefore, the estimated numbers of cells of each type were based on counts of six $10000 \mu \mathrm{m}^{2}$ fields.

Cell types for each section were summed and expressed as means \pm SEM per $60000 \mu \mathrm{m}^{2}$ for each experimental group. In addition, the apoptotic score was expressed as a percentage of the total number of cells per $60000 \mu \mathrm{m}^{2}$.

Identification of cell types. Morphologically normal steroidogenic cells were defined as being $>12 \mu \mathrm{m}$ in diameter with regular circular outlines in section, abundant cytoplasm and circular nuclei. Cells with these morphological characteristics have been shown to be positive for the steroidogenic enzyme $3 \beta$ hydroxysteroid dehydrogenase after routine immunocytochemistry both by others (Webley et al., 1990; Fehrenbach et al., 1995) and in our laboratory (results not shown).

Morphologically abnormal steroidogenic cells were characterized by changes in the cytoplasm. These changes varied from essentially intact cells containing small vacuoles (2-4 $\mu \mathrm{m}$ diameter) to extreme disruption of the cytoplasm leaving a remnant around the nucleus combined with the presence of 3-5 large vacuoles $(6-10 \mu \mathrm{m}$ diameter). 
Apoptosis was characterized both by individual clusters of apoptotic bodies, where each cluster was assumed to have originated from the fragmentation of one cell, and by condensed cells with clearly fragmented nuclei. Apoptotic bodies with the morphological appearance seen in our sections have been shown to contain the condensed chromatin and intact organelles characteristic of apoptosis when examined under an electron microscope (Howie et al., 1994).

Cell types that did not conform to any of the above definitions were defined as non-steroidogenic cells. These were generally elongated with long axes of $4-8 \mu \mathrm{m}$, large nuclei and little cytoplasm. Since they frequently enclosed lumina containing red blood cells, the majority of these cell types were assumed to be endothelial cells.

\section{In situ $3^{\prime}$ end labelling}

Paraformaldehyde-fixed sections were rehydrated by transferring the slides through two troughs of xylene ( $5 \mathrm{~min}$ in each) and $1 \mathrm{~min}$ in each of $100 \%, 95 \%$ and $70 \%$ ethanol. Endogenous peroxidase was blocked by incubation for 30 min in $3 \% \mathrm{H}_{2} \mathrm{O}_{2}$ (BDH Laboratory Supplies, Poole) in methanol. Washing with PBS was followed by incubation for $45 \mathrm{~min}$ in $5 \mu \mathrm{g}$ proteinase $\mathrm{K} \mathrm{ml}^{-1}$ (Sigma, Poole) in PBS at $37^{\circ} \mathrm{C}$. Slides were transferred to Sequenza racks (Life Sciences International, Basingstoke) and rinsed three times in PBS. Positive control sections were incubated for $10 \mathrm{~min}$ at $37^{\circ} \mathrm{C}$ in $5 \mu \mathrm{g} \mathrm{DNase} \mathrm{ml}^{-1}$ (Boehringer Mannheim, Lewes) in buffer (30 mmol Tris- $\mathrm{HCl} \mathrm{I}^{-1}$ (Sigma) pH 7.2, 140 mmol sodium cacodylate $\mathrm{l}^{-1}$ (Agar Scientific Ltd, Stansted), $4 \mathrm{mmol} \mathrm{MgCl}_{2} \mathrm{1}^{-1}$ (BDH Laboratory Supplies) $0.1 \mathrm{mmol} \mathrm{DTT} ~^{-1}$ (Promega, Southampton), and then rinsed once in TE buffer $\left(0.1 \mathrm{~mol}\right.$ Tris- $\left.\mathrm{HCl} 1^{-1}, 0.05 \mathrm{~mol} \mathrm{EDTA}^{-1}\right)$ and three times in PBS. $3^{\prime}-\mathrm{OH}$ ends of DNA fragments were labelled with $0.5 \mathrm{nmol}$ digoxigenin-11-UTP $1^{-1}$ (Boehringer Mannheim) by 50 i.u. $\mathrm{ml}^{-1}$ terminal deoxynucleotidyl transferase (TdT, Boehringer Mannheim) in buffer $(30 \mathrm{mmol}$ Tris$\mathrm{HCl} \mathrm{l}^{-1}$ (Sigma) $\mathrm{pH} 7.2,140 \mathrm{mmol}$ sodium cacodylate $\mathrm{l}^{-1}$ (Agar Scientific Ltd), $1.5 \mathrm{mmol} \mathrm{CoCl}_{2} \mathrm{I}^{-1}$ (Boehringer Mannheim) for $1 \mathrm{~h}$ at $37^{\circ} \mathrm{C}$. Negative control sections had the TdT replaced by the equivalent amount of buffer. Four rinses with PBS were followed by incubation with horseradish peroxidase conjugated sheep anti-digoxigenin antibodies (Boehringer Mannheim) 1.5 i.u. $\mathrm{ml}^{-1}$ in buffer $(100 \mathrm{mmol}$ Tris- $\mathrm{HCl}^{-1}$ (Sigma) pH 7.5, $150 \mathrm{mmol} \mathrm{NaCl}{ }^{-1}$ ) for $30 \mathrm{~min}$ at room temperature. Three PBS washes were followed by visualization with $0.04 \%(\mathrm{w} / \mathrm{v}) 3,3^{\prime}$-diaminobenzidine (Sigma) in $0.05 \mathrm{~mol}$ Tris- $-\mathrm{HCl} \mathrm{l}^{-1}$ (Sigma) $\mathrm{pH} 8$ and $3 \% \mathrm{H}_{2} \mathrm{O}_{2}$ (BDH Laboratory Supplies).

Quantification of $3^{\prime}$ end labelled sections. Each ovary was 3' end labelled on at least three separate occasions. The results presented are taken from one representative $3^{\prime}$ end labelling run. The DNase positive controls and test sections were viewed with a $\times 20$ objective lens. The $3^{\prime}$ end labelled nuclei were counted in three randomly selected fields of view of luteal tissue using an NIH Image Analysis 1.57 programme and the mean was calculated and expressed as the number of positive nuclei per $\times 20$ field of view. Data for $3^{\prime}$ end labelling in test sections were expressed as percentages of values seen in DNase-positive controls.

\section{Localization of lipids}

Cryostat sections were stained with $\mathrm{Oil}$ Red $\mathrm{O}$ in isopropanol (Sigma) for $15 \mathrm{~min}$ at $37^{\circ} \mathrm{C}$, differentiated in $60 \%$ isopropanol for $5 \mathrm{~min}$, washed in water and counterstained with haematoxylin (Bayliss High, 1982).

\section{Progesterone assay}

The progesterone concentrations in plasma were determined by radioimmunoassay as described by Smith et al. (1990). The sensitivity of the assay was $0.07 \mathrm{pmol}$ per tube and the interand intra-assay coefficients of variation were $15 \%$ and $4 \%$, respectively.

\section{Statistical analysis}

Data obtained from the morphological analysis of sections of naturally regressing corpora lutea stained with haematoxylin and eosin are expressed as means \pm SEM and were subjected to one-way analysis of variance taking the stage of the cycle as a between-subject variable. Differences between mean values obtained from the morphological analysis of corpora lutea induced to undergo regression with cloprostenol or antarelix were compared among experimental groups and with untreated corpora lutea from day 10 of the luteal phase in a separate one-way analysis of variance taking the nature of treatment as a between-subject variable. When a significant $F$ value was obtained the data were further analysed by Scheffé's test, and significance was assigned at $P<0.05$.

Results from the $3^{\prime}$ end labelled sections are expressed as means of $3^{\prime}$ end-labelled positive cells per 100 cells counted \pm SEM. The data were subjected to chi-squared analysis and significance was assigned at $P<0.05$.

\section{Results}

\section{Progesterone}

Progesterone concentrations during the ovarian cycles preceding ovarian collection are shown (Fig. 1). In the ovarian cycle preceding luteolytic treatment and ovarian collection, the mean follicular phase concentration of progesterone for all the animals studied was $16 \pm 4 \mathrm{nmol} 1^{-1} \quad(n=18)$. The mean progesterone concentration increased to $172 \pm 50 \mathrm{nmol} \mathrm{l}^{-1}$ by day 2 of the luteal phase, was $206 \pm 64 \mathrm{nmol} \mathrm{I}^{-1}$ from luteal day 3 to day 12 , and decreased to $39 \pm 9 \mathrm{nmol} \mathrm{l}^{-1}$ by day 18 (Fig. 1a, b).

Progesterone concentrations for animals whose ovaries were collected on days 10 and 18 of the luteal phase were $206 \pm 104 \mathrm{nmol}^{-1}(n=4)$ and $226 \pm 51 \mathrm{nmol} 1^{-1}(n=3)$, respectively, at the time of collection (Fig. 1a). Progesterone concentrations of animals whose ovaries were collected in the early follicular phase (equivalent to day 22 of the luteal phase) were $12.7 \pm 0 \mathrm{nmol} \mathrm{l}^{-1}(n=3)$ at the time of collection 
(a)
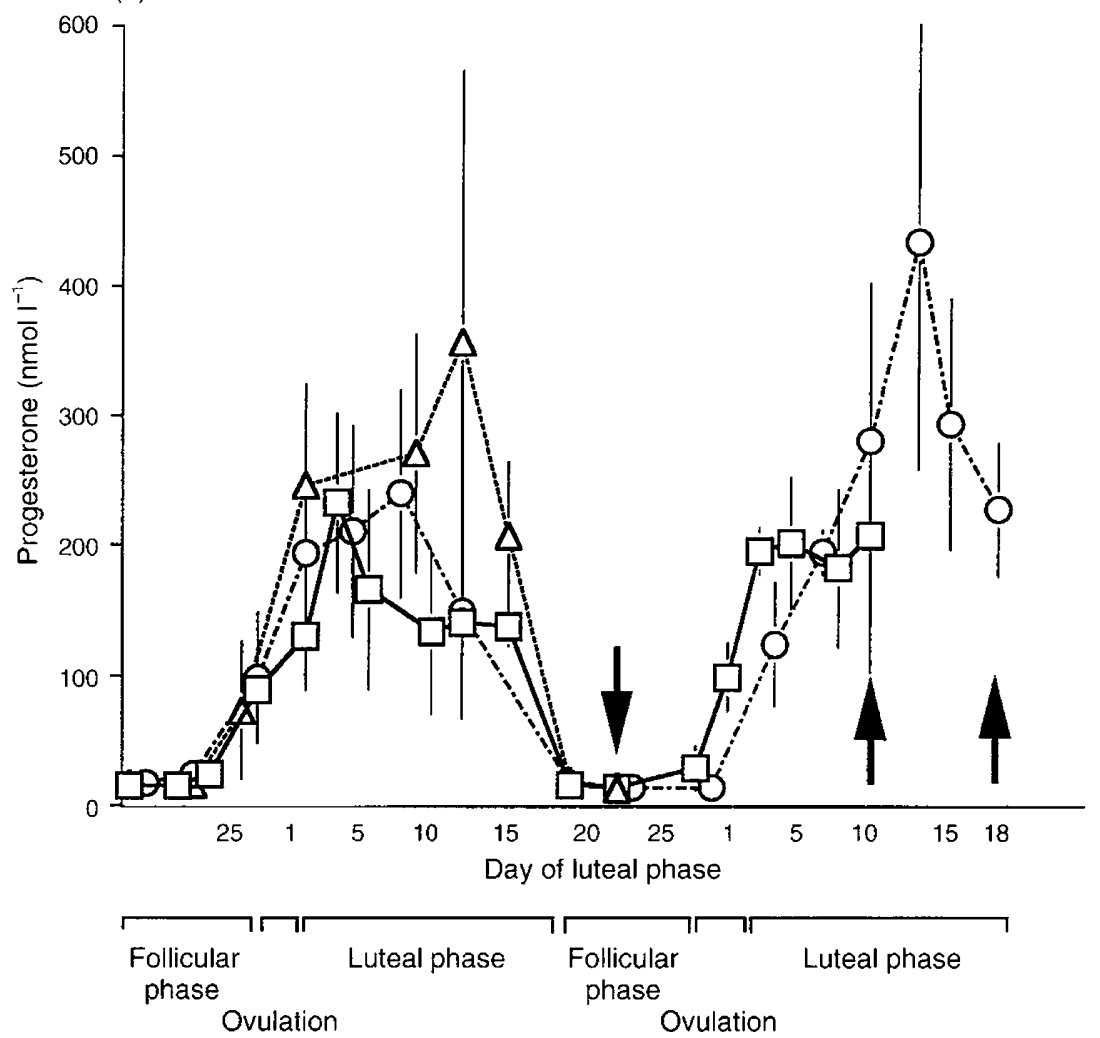

(b)
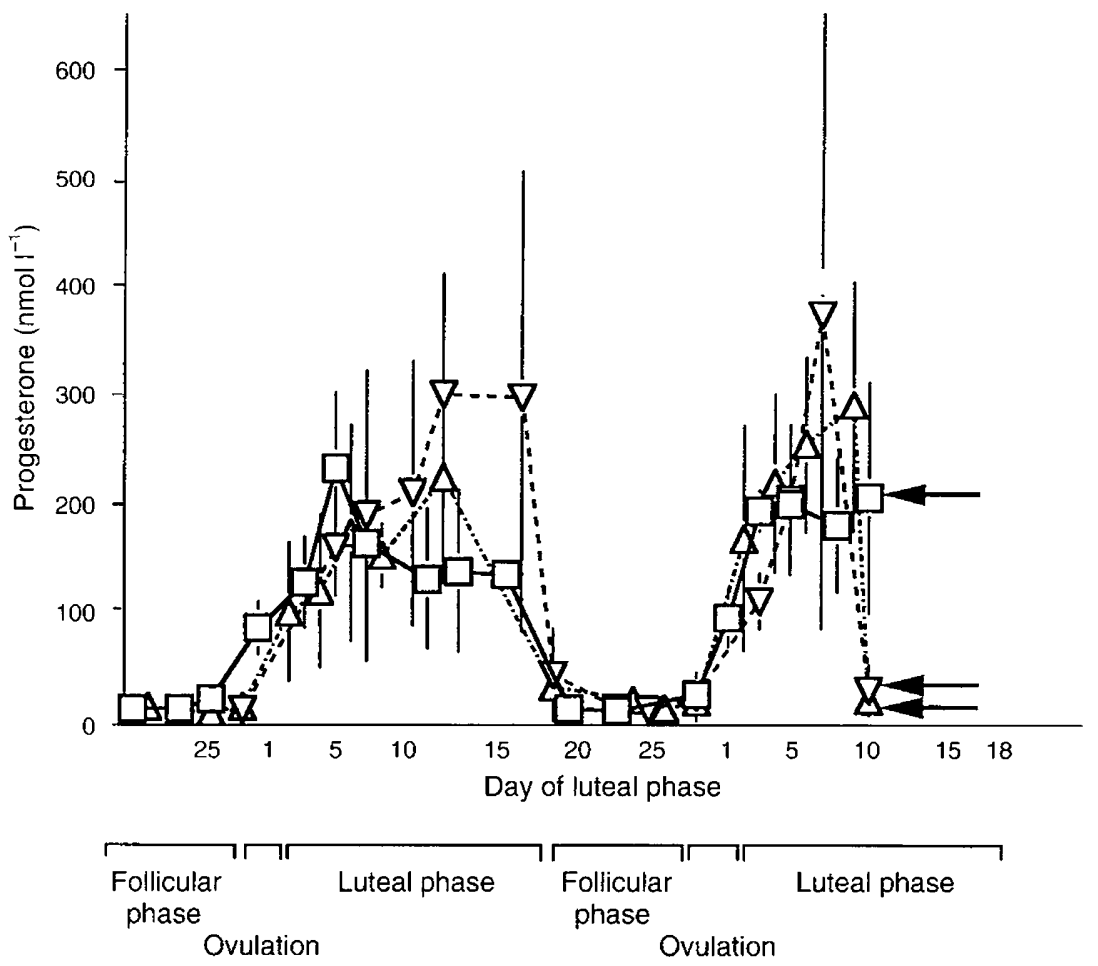

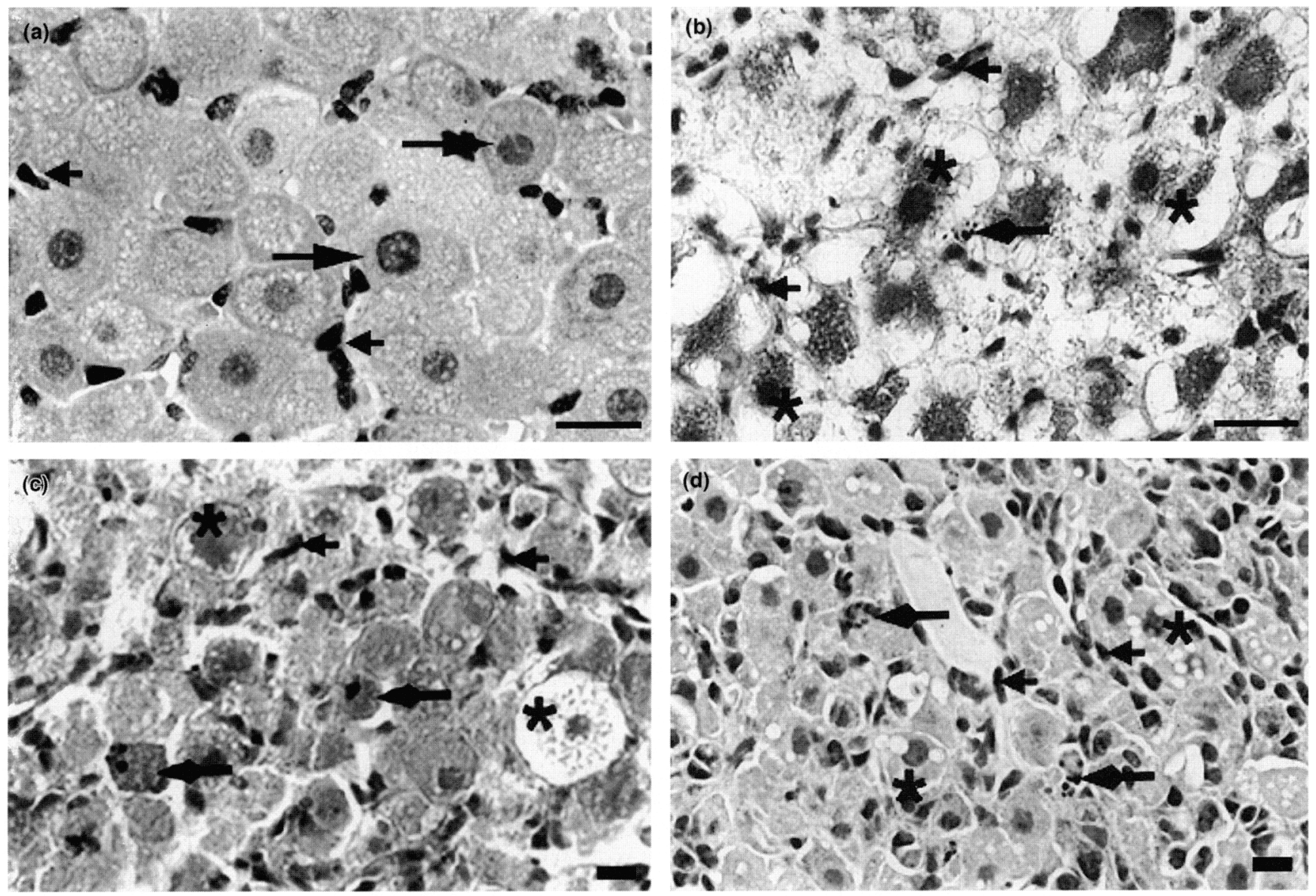

Fig. 2. Haematoxylin and eosin-stained, paraformaldehyde-fixed sections of marmoset corpus luteum obtained from animals at (a) untreated mid-luteal phase, (b) mid-luteal phase $24 \mathrm{~h}$ after administration of a GnRH antagonist, (c) mid-luteal phase $24 \mathrm{~h}$ after administration of prostaglandin $\mathrm{F}_{2 a}$ analogue, and (d) untreated early follicular-late luteal day 22. Morphologically normal steroidogenic cells (large, right-pointing arrows), non-steroidogenic cells (small, left-pointing arrows), apoptotic cells or apoptotic bodies (left-pointing diamond arrowhead), and vacuolated steroidogenic cells (asterisk) are indicated. Scale bars represent $20 \mu \mathrm{m}$.

(Fig. Ia). Plasma progesterone concentrations of animals treated with antarelix and cloprostenol were $372 \pm 284(n=4)$ and $289 \pm 213(n=4)$ nmol l-1 ${ }^{-1}$, respectively, before treatment on luteal day 9 (Fig. Ib). Luteolytic treatment resulted in a marked decrease to $32 \pm 23 \mathrm{nmol}^{-1}$ and $23 \pm 10 \mathrm{nmol}^{-1}$ for antarelix and cloprostenol treated animals, respectively (Fig. Ib). No significant differences were found between the progesterone concentrations before treatment in any of the study groups.

\section{Histology of luteal tissue}

Steroidogenic cells in untreated day 10 corpora lutea had abundant cytoplasm and regular, circular nuclei (Fig. 2a).
Non-steroidogenic cells had little cytoplasm and elongated nuclei. Steroidogenic cells were commonly in close juxtaposition with non-steroidogenic cells, which appeared to form a network surrounding the steroidogenic cells. Mid-luteal phase tissue had a regular, close-packed structure (Fig. 2a) which was in marked contrast to the disorganized, irregular structure of tissues undergoing luteal regression (Fig. 2b-d).

The morphology of non-steroidogenic cells did not appear to change after luteolysis, unlike the parenchymal steroidogenic cells, which exhibited a range of cytoplasmic changes apparently brought about by the formation of vacuoles. The vacuoles in naturally regressing corpora lutea from the early follicular phase were small and discrete, and were not present in all steroidogenic cells (Fig. 2d). The proportion of vacuolated cells, and the size of the vacuoles, had increased by the late

Fig. 1. (a) Mean ( \pm SEM) plasma concentrations of progesterone (nmol $\mathrm{l}^{-1}$ ) through the study period in marmosets where ovaries were collected on mid-luteal day $10(n=4, \square)$, late luteal day $18(n=3,0)$ and early follicular-late luteal day $22(n=3, \triangle)$. The arrows indicate the day of collection. (b) Mean ( \pm SEM) plasma concentrations of progesterone $\left(\mathrm{nmol} \mathrm{l}^{-1}\right)$ in marmosets before and after administration of $I \mu \mathrm{g}$ prostaglandin $\mathrm{F}_{2 a}$ analogue, i.m. $(n=4, \triangle)$ or $1 \mathrm{mg} \mathrm{GnRH}$ antagonist $\mathrm{kg}^{-1}$ s.c. $(n=4, \nabla)$ on day 9 of the luteal phase. Ovaries were collected $24 \mathrm{~h}$ later on day 10 of the luteal phase. Data are also shown for control marmosets $(n=4)$ which were given no treatment $(\square)$. The arrows indicate the day of ovarian collection. 
follicular phase. Steroidogenic cell vacuolation also occurred after luteolytic treatment, but the vacuoles were larger than those seen in naturally regressing corpora lutea and the steroidogenic cells had an oedematous appearance commonly associated with necrosis (Bowen, 1984). The majority of steroidogenic cells in the corpora lutea from animals treated with antarelix appeared oedematous (Fig. 2b), whereas in the animals treated with cloprostenol, the proportion of vacuolated cells was more variable. Some areas contained only a few vacuolated cells while other areas consisted predominantly of vacuolated cells (Fig. 2c).

Apoptotic bodies were found in all corpora lutea and had the appearance of clusters of small irregular spheres with intense haematoxylin staining (Fig. 2b-d). Cells in the final stages of apoptosis had condensed cytoplasm and nuclear fragments that exhibited the same intense haematoxylin staining as that seen in apoptotic bodies (Fig. 2b, c). There was no obvious separation of apoptotic and vacuolated cells, with the two types found commonly in close juxtaposition.

\section{Morphometric analysis of haematoxylin and eosin sections}

The number of morphologically normal steroidogenic cells per $60000 \mu \mathrm{m}^{2}$ of luteal tissue was similar in the mid- and late luteal phase and in the early follicular phase corpora lutea (Fig. 3a); however, when compared with the untreated midluteal phase (104 \pm 25 ), the number of morphologically normal steroidogenic cells was significantly decreased in naturally regressing corpora lutea from the late follicular phase (18.3 $\pm 5.2 ; P<0.001)$ as well as in corpora lutea in which regression was induced with either cloprostenol ( $34 \pm 12.7$; $P<0.001)$ or antarelix $(1.25 \pm 1.7 ; P<0.001$; Fig. 3a). The number of non-steroidogenic cells was similar in all groups except the early follicular phase group $(249 \pm 63)$ which had significantly more non-steroidogenic cells than either the untreated mid-luteal phase $(120 \pm 30 ; P<0.05)$ or the late follicular phase corpora lutea $(97.3 \pm 69 ; P<0.05$; Fig.3b).

A small number of cells exhibiting the morphological appearance of apoptosis was observed in all corpora lutea studied, including those in the mid-luteal phase $(0.75 \pm 0.6$; Fig 3c). The number of cells exhibiting these features was significantly increased to $15 \pm 4(P<0.001$; Fig. $3 c)$ in naturally regressing corpora lutea from the early follicular phase, but was similar in corpora lutea from the late luteal $(2.0 \pm 0.94)$ and late follicular (3.66 \pm 3.2 ) phases.

The number of cells having the morphological appearance of apoptosis was significantly increased after cloprostenol-induced regression (24 $\pm 5.6 ; P<0.001 ; \mathrm{Fig} 3 \mathrm{c}$ ) but, although the occurrence of apoptotic cells was apparently increased after treatment with antarelix, this response was variable and not statistically significant.

The number of vacuolated cells increased gradually with advancing luteal age and was significantly higher in naturally regressing corpora lutea from the late follicular phase compared with all other naturally regressing corpora lutea (Fig. 3d). The numbers of vacuolated cells were similarly significantly higher after luteolytic treatment compared with untreated mid-luteal phase corpora lutea $(P<0.001)$.

\section{$3^{\prime}$ end labelling}

The extent of $3^{\prime}$ end labelling was low in sections of corpus luteum from untreated animals on luteal day $10(0.675 \pm 0.427$; Figs $4 \mathrm{a}$ and 5 ). Nearly all nuclei were labelled in positive control sections pretreated with DNase (Fig. 4 b) and there was no labelling at all in negative control sections in which $\mathrm{TdT}$ was omitted from the labelling buffer (Fig. 4c). The amount of $3^{\prime}$ end labelling was significantly increased to $5.54 \pm 1.4$ $(P<0.01)$ in corpora lutea collected on luteal day 22 in the early follicular phase (Fig. 5). Labelled cells had large regular nuclei and abundant cytoplasm, which are both features characteristic of steroidogenic cells. Cells with elongated nuclei and little cytoplasm were also $3^{\prime}$ end labelled; these were identified as being non-steroidogenic and possibly endothelial. As a positive internal control, granulosa cells undergoing apoptosis in atretic follicles were $3^{\prime}$ end labelled in ovaries from all experimental groups whereas little or no labelling was seen in healthy follicles (Fig. 4e).

Corpora lutea induced to undergo regression with cloprostenol and antarelix, respectively, were labelled in $6.25 \pm 1.2$ and $7.4 \pm 1.5$ of cells per hundred cells scanned; this incidence of labelling was significantly higher than those seen in untreated corpora lutea at day $10(0.675 \pm 0.4 ; P<0.01$; Fig. $5)$. The labelling seen in corpora lutea treated with antarelix was in structures resembling apoptotic bodies, and was occasionally seen in the bodies of cytoplasm assumed to have originated from steroidogenic cells (Fig. 4f). The majority of vacuolated cells had no observable nucleus but, in such cells in which nuclei were present, a small proportion showed positive nuclear staining. In corpora lutea from animals treated with cloprostenol, nuclear labelling was generally associated with vacuolated cells that still contained relatively abundant cytoplasm and were thus assumed to originate from steroidogenic cells (Fig. 4g). Apoptotic bodies were also labelled in corpora lutea from animals treated with cloprostenol. In corpora lutea from animals treated with either antarelix or cloprostenol, labelling also occurred in a small proportion of cells, the morphological appearance and location of which indicated that they were vascular endothelial cells.

\section{Lipid staining}

In control ovaries at day 10 , the most intense staining for Oil Red $\mathrm{O}$, with variable droplet size, was seen in localized areas of the stroma containing cells having the appearance of steroidogenic cells and which were assumed to represent differentiated interstitial cells. In a proportion of antral follicles, intense staining was also seen within the thecal layer while granulosal staining was not recorded in follicles of any size. There was no staining in small antral or preantral follicles. Within luteal tissue, staining was variable and generally more intense in corpora lutea accessoria (CLA) than in the true corpora lutea. Oil Red O staining represents lipid accumulation and its occurrence in luteal tissue in the untreated ovary is illustrated (Fig. 4h,i).

After treatment with either antarelix or cloprostenol, the distribution of staining within the non-luteal compartments remained unchanged. In luteal tissue, there was little to suggest lipid accumulation; in particular, vacuoles did not contain lipid 
(a)

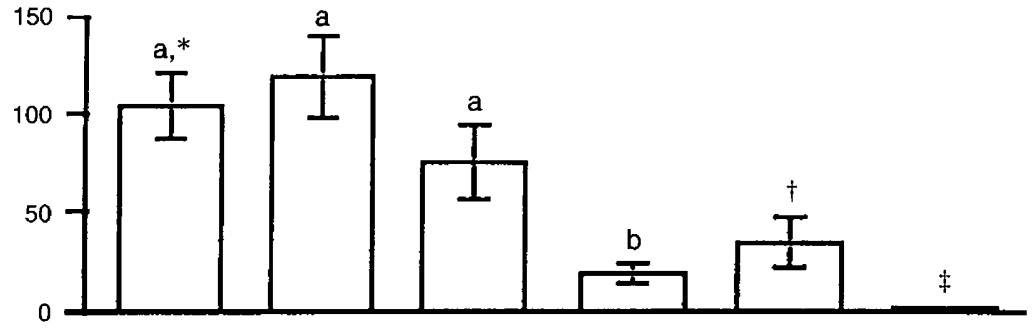

(b)

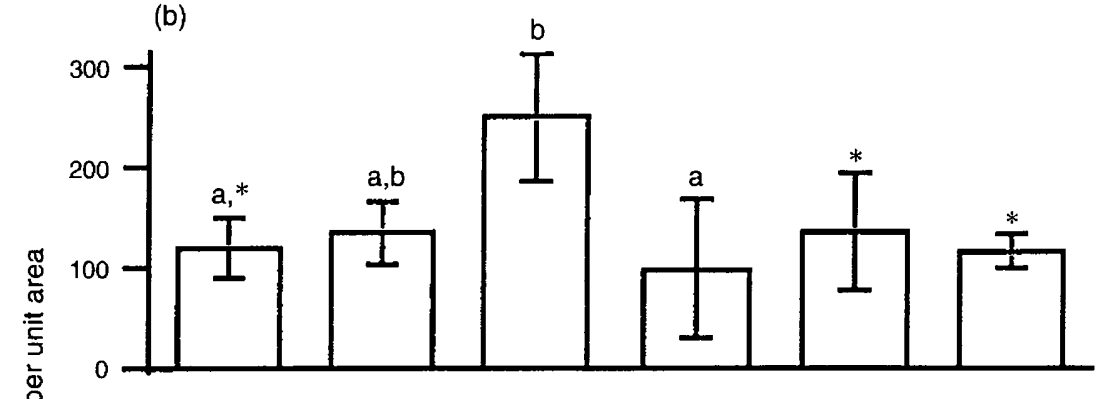

(c)

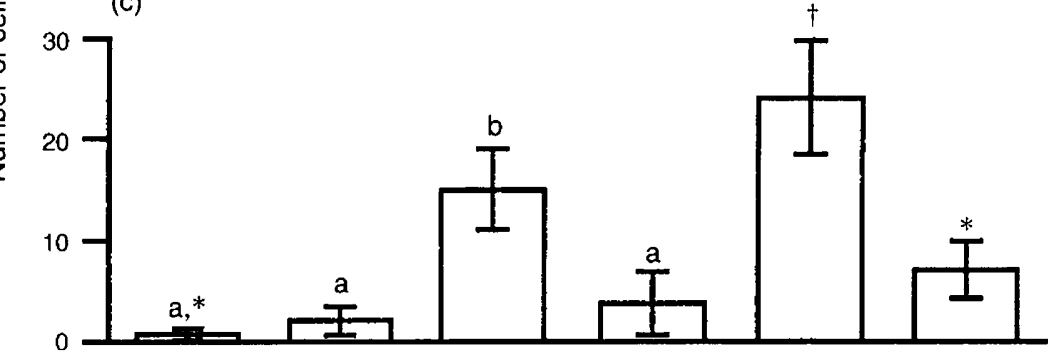

(d)

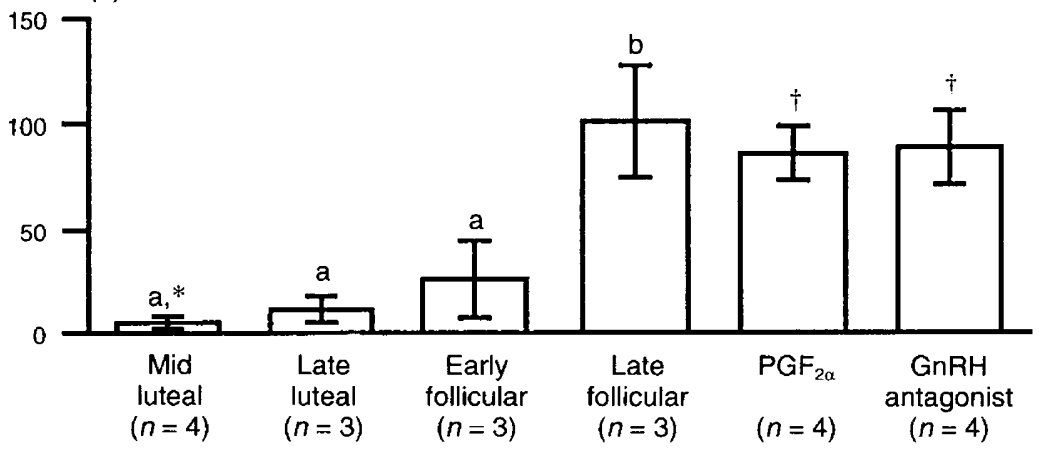

Fig. 3. Mean ( \pm SEM) number of cells per $60000 \mu \mathrm{m}^{2}$ area of marmoset luteal tissue in haematoxylin and eosin stained sections of (a) morphologically normal steroidogenic cells, (b) non-steroidogenic cells, (c) apoptotic cells or apoptotic bodies, and (d) vacuolated steroidogenic cells in corpora lutea. Data are shown for ovaries collected on day 10 and day 18 of the luteal phase and early and late follicular phases (equivalent to day 22 and day 26 of the luteal phase) as well as those collected on luteal day 10 at $24 \mathrm{~h}$ after administration of prostaglandin $\mathrm{F}_{2 a}\left(\mathrm{PGF}_{2 a}\right)$ analogue or a $\mathrm{GnRH}$ antagonist. ${ }^{\mathrm{ab}}$ Columns with different superscript letters show significant differences among stages of the cycle (a, c, d: $P<0.01$; b: $P<0.05$ ). ${ }^{* \dagger+}$ Columns with different symbols show significant differences $(P<0.01)$ among ovaries treated with $\mathrm{PGF}_{2 u}$ analogue and $\mathrm{GnRH}$ antagonist treatments and mid-luteal stage control. 

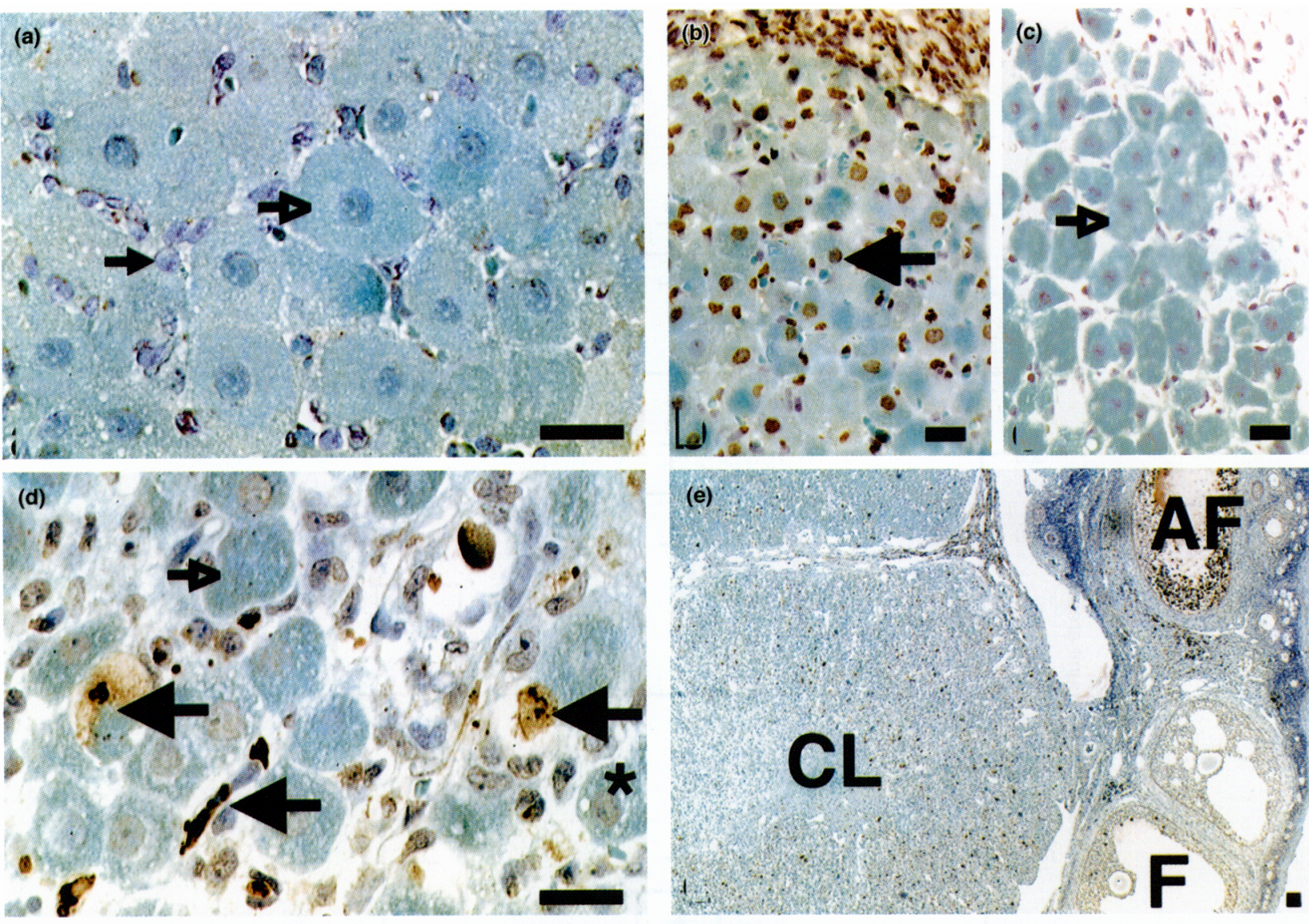

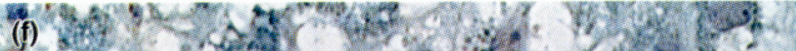

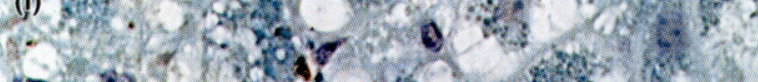

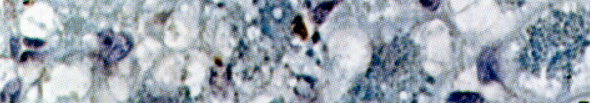

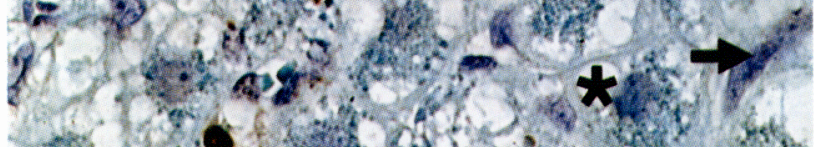

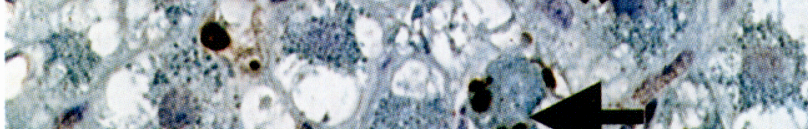

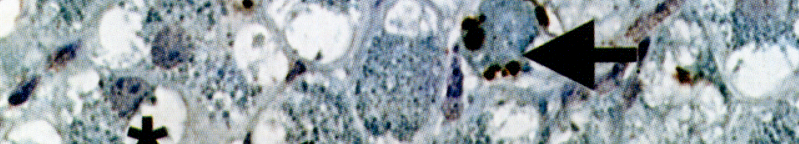
K.

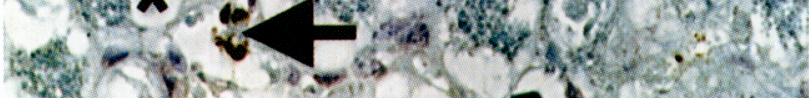

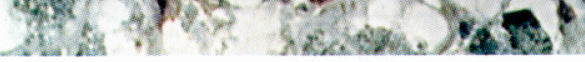
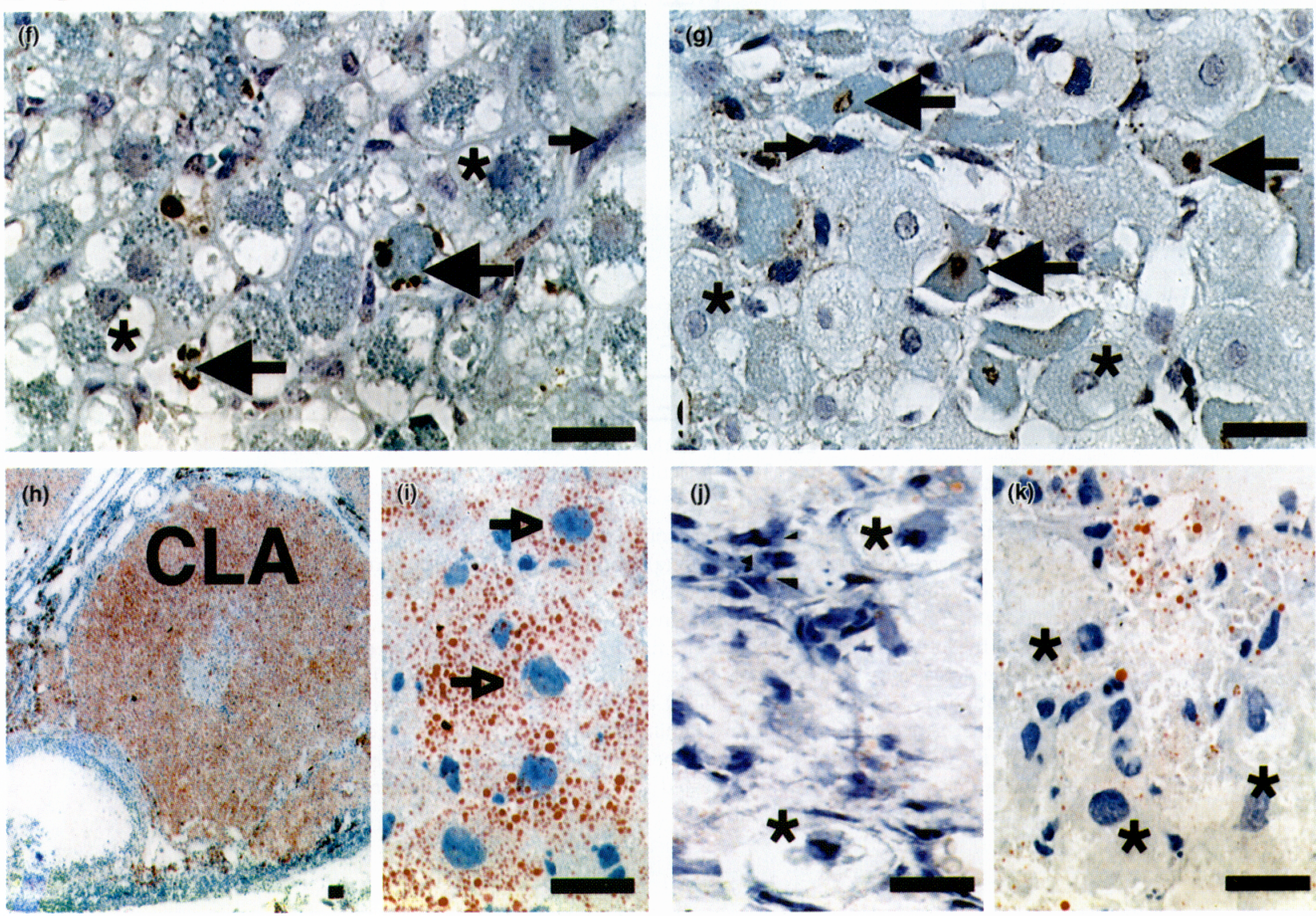




15

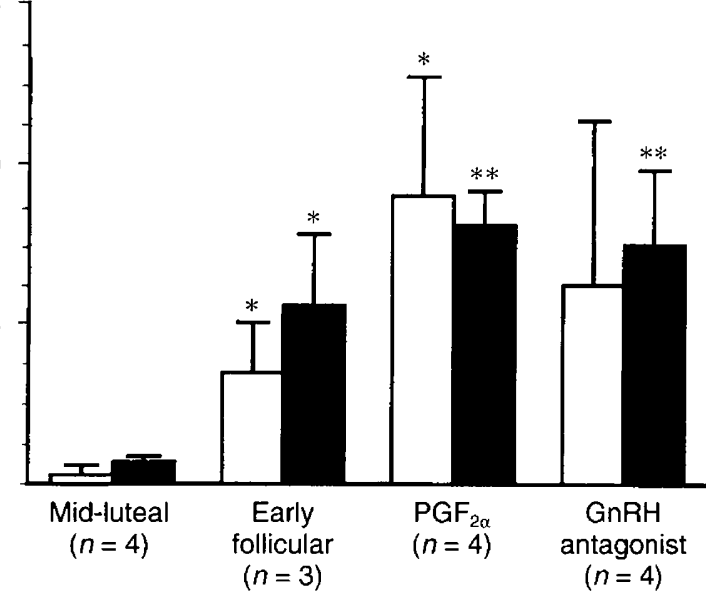

Fig. 5. Mean ( \pm SEM) number of apoptotic cells and apoptotic bodies per 100 cells in marmoset corpora lutea collected during the mid-luteal phase (luteal day 10), early follicular phase (equivalent to late luteal day 22), mid-luteal phase $24 \mathrm{~h}$ after administration of a prostaglandin $\mathrm{F}_{2 a}\left(\mathrm{PGF}_{2 u}\right)$ analogue, and mid-luteal phase $24 \mathrm{~h}$ after administration of a GnRH antagonist. ( $\square$ ) Apoptotic scores generated by highly optimized microscope environment (HOME) analysis of haematoxylin and eosin stained ovarian sections; ( $\boldsymbol{(}$ ) apoptotic scores generated by image analysis of in situ $3^{\prime}$ end-labelled ovarian sections. Significant differences are indicated by asterisks $\left({ }^{*} P<0.05 ;{ }^{*} P<0.01\right)$.

droplets, which were primarily extracellular, probably as a direct result of the regressive changes (Fig. $4 \mathrm{j}-\mathrm{k}$ ).

\section{Discussion}

These studies describe and quantify morphological changes occurring during natural and induced luteal regression in marmoset monkeys. A significant amount of apoptosis has been identified in the regressing primate corpus luteum. In addition, extensive cell death caused by a process other than apoptosis was observed.

Both the $3^{\prime}$ end labelled technique and morphological analysis demonstrated that apoptosis increased only after peripheral progesterone concentrations had decreased to follicular phase values. Apoptosis also increased after induced luteolysis. These results are in agreement with studies that showed an increase in apoptosis when progesterone concentrations have decreased after $\mathrm{PGF}_{2 a}$-induced luteolysis in sheep (Rueda et al., 1995) and cattle (Juengel et al., 1993; Zheng et al., 1994). Thus, apoptosis does not appear to be a cause of functional luteolysis.

The finding that significant changes in the amount of apoptosis in the tissue do not occur until after the decrease in progesterone concentration differs from results obtained in a recent study on the human corpus luteum (Shikone et al., 1996), in which in situ $3^{\prime}$ end labelling and analysis of oligonucleosome formation in total luteal DNA showed a significant amount of apoptosis in the mid-luteal phase corpus luteum rising to $40-57 \%$ of cells in the late luteal phase. In marmosets, the percentage of $3^{\prime}$ end labelled cells was only $0.67 \pm 0.18 \%$ in corpora lutea from untreated animals at mid-luteal phase (day 10 ), and increased to $5.5 \pm 2.2 \%$ of all luteal cells in the early follicular phase of the subsequent cycle (equivalent to day 20-22 of the luteal phase). Shikone et al (1996) also report DNA degradation characteristic of necrosis, and noted that their in situ labelling technique did not differentiate between cells undergoing apoptosis and necrosis. This may bring into question the value of this method as a measure of apoptosis when used in a tissue that is undergoing regression by a combination of apoptosis and necrosis.

In the present study, the rationale for using the $3^{\prime}$ end labelling technique, as opposed to morphological analysis alone, was that the former technique may detect apoptotic cells at an earlier stage and allow the type of cell to be confirmed. Once morphological changes have occurred, it is difficult or impossible to determine the nature of the cell from which the apoptotic bodies were derived. Our results demonstrated that the majority of labelled cells were steroidogenic, although a small proportion of endothelial cells, particularly in the spontaneously regressing corpus luteum, were also labelled.

The percentage of $3^{\prime}$ end labelled cells is highly dependent upon the concentration and duration of the proteinase $\mathrm{K}$ incubation, and on the nature of the tissue being examined. In this study, these parameters were optimized to achieve the amount of positive $3^{\prime}$ end labelling reported in healthy and atretic follicles (Billig et al., 1993; Tilly, 1993; Hsueh et al., 1994). Under these conditions, positive controls treated with DNase were slightly under-labelled $(90-98 \%)$, indicating a possible underestimation of apoptosis using this method. Although the data described are inappropriate for quantifying

Fig. 4. In situ 3' end labelled, paraformaldehyde-fixed and Oil Red O-stained frozen marmoset ovarian sections. (a) 3' End-labelled section of marmoset corpus luteum (day 10 of luteal phase). A morphologically normal steroidogenic cell (open arrow) and non-steroidogenic cell (closed arrow) are indicated. (b) Positive control (DNase pretreated, $3^{\prime}$ end-labelled) serial section of (a) (the arrow indicates a $3^{\prime}$ end-labelled nucleus). (c) Negative control (terminal deoxynucleotidyl transferase omitted) serial section of (a). (d) 3' End-labelled section of marmoset corpus luteum (day 22 of the luteal phase). $3^{\prime}$ End-labelled cells and apoptotic bodies (closed arrows) and vacuolated steroidogenic cells (*) are indicated. (e) Low powered view of the same day $22,3^{\prime}$ end labelled section of marmoset ovary showing localization of label within the CL and between follicles. $\mathrm{CL}$, corpus luteum; AF, atretic follicle; F, healthy antral follicle. (f) $3^{\prime}$ End-labelled section of marmoset corpus luteum, $24 \mathrm{~h}$ after administration of a GnRH antagonist. $3^{\prime}$ End-labelled cells and apoptotic bodies (large, left-pointing closed arrows), a non-steroidogenic cell (small, right-pointing arrow), and vacuolated cells $\left(^{*}\right)$ are indicated. $(\mathrm{g}) 3^{\prime}$ End-labelled section of marmoset corpus luteum $24 \mathrm{~h}$ after administration of a prostaglandin $\mathrm{F}_{2 u}\left(\mathrm{PGF}_{2 u}\right)$ analogue. $3^{\prime}$ End-labelled cells and apoptotic bodies (large, left-pointing arrows), non-steroidogenic cells (small, right-pointing arrow) and vacuolated cells $\left(^{*}\right)$ are indicated. (h) Low power Oil Red O-stained section of marmoset accessory luteal tissue on day 10 of the luteal phase. CLA, corpora lutea accessoria. (i) High power Oil Red O-stained section of marmoset CLA on day 10 of the luteal phase. Open-headed arrows indicate lipid within the cytoplasm of steroidogenic cells. (j) Oil Red O-stained section of marmoset corpus luteum, $24 \mathrm{~h}$ after administration of a GnRH analogue showing the absence of lipid within vacuolated cells $\left(^{*}\right)$. ( $\mathrm{k}$ ) Oil Red O-stained frozen section of marmoset corpus luteum $24 \mathrm{~h}$ after administration of a PGF ${ }_{2 u}$ analogue showing extracellular localization of lipid. Scale bars represent $20 \mu \mathrm{m}$. 
absolute amounts of apoptosis, they do give an excellent indication of the relative amounts of apoptosis in natural compared with induced luteal regression.

However, the use of the $3^{\prime}$ end labelling technique may be compromised in situations in which apoptosis is occurring in association with other forms of cell death. This situation was seen to occur after luteal regression induced pharmacologically, where a proportion of positively labelled cells was observed to be vacuolated.

The observation of extensive cell death caused by a process other than apoptosis was suggested by earlier findings in this species (Fraser et al., 1995), after induction of luteolysis by a prostaglandin analogue or a GnRH antagonist. In both this and the earlier study, treatment resulted in the development of large vacuoles, or vesicles, within the cytoplasm of the steroidogenic cells. A proportion of the steroidogenic cells in naturally regressing corpora lutea was also vacuolated. At day 22 of the luteal phase, these vacuoles were smaller and qualitatively different from those seen after induced luteolysis, but both the proportion of vacuolated cells and the size of the vacuoles increased as the corpus luteum regressed spontaneously in the late follicular phase (corresponding to days $24-28$ of the preceding luteal phase). Induction of luteolysis may occur by a rapid suppression of steroidogenesis, raising the possibility that the vacuolation observed was a result of accumulation of lipid substrate. However, Oil Red $\mathrm{O}$ staining of frozen sections indicated that vacuoles are not filled with lipid in pharmacological luteolysis, although the equivalent study has not yet been done in naturally regressing corpora lutea owing to unavailability of suitable frozen tissue. Accumulation of lipid has been shown to occur in the naturally regressing sheep corpus luteum (Deane et al., 1966) and it is possible that the vacuolation in the naturally regressing marmoset corpus luteum may also be a consequence of lipid accumulation.

The presence of a form of cell death other than apoptosis has also been reported in other species (Rueda et al., 1995). Vacuolation in steroidogenic cells has been reported in rat corpora lutea after administration of the $\mathrm{PGF}_{2 a}$ analogue, cloprostenol (Salazar et al., 1976). In a classic study of the human corpus luteum (Corner, 1956), cells in which the cytoplasm is almost completely obscured by several large vacuoles' were noted to appear by day 12 of the luteal phase, and the number of vacuolated cells was found to increase as the corpus luteum regressed. Steroidogenic cells described in this study as 'vacuolated' were found to have many of the morphological features of cells that are becoming necrotic: chromatin aggregation, nuclear pyknosis, loss of compartmentalisation and cell oedema (Trump et al., 1981). Necrosis occurs as a consequence of an extracellular event such as exposure to a toxin and is generally thought to represent an inflammatory response to a pathological stimulus (Bowen, 1984). In contrast, luteal regression is a physiological process with no obvious inflammatory response. Secondary necrosis has been reported to occur after apoptosis, but vacuolated cells within regressing corpora lutea have clearly intact nuclei, indicating that they have not undergone apoptosis before vacuolation. A form of cell death that is neither apoptosis nor necrosis but is characterized by vacuolation has been reported in neuronal cell cultures (Regan et al., 1995) and in developing tissues (Clarke, 1990) where it has been referred to as 'autophagic degeneration'. In addition, Fehrenbach et al. (1995) reported vacuolization in marmoset corpora lutea in vitro after dialysis of culture media. Further ultrastructural studies are required to examine this non-apoptotic form of cell death in the primate corpus luteum.

In conclusion, apoptosis occurs in regressing marmoset corpora lutea as shown by morphological analysis and by $3^{\prime}$ end labelling. The majority of apoptotic cells were found to be steroidogenic while a small proportion of presumptive endothelial cells were also labelled, particularly after naturally occurring luteolysis. The widespread occurrence of another form of cell death has been detected, which is characterized by the formation of cytoplasmic vacuoles in steroidogenic cells.

The authors thank K. D. Morris and staff for animal care, G. M. Cowen and M. Millar for skilled technical support, colleagues in the Centre for Reproductive Biology for assisting in the provision of some of the ovarian tissue, and R. Deghenghi (Europeptides) for the gift of antarelix.

\section{References}

Bayliss High OB (1982) Lipids. In Theory and Practice of Histological Techniques pp 218-241 Eds JD Bancroft and A Stevens. Churchill Livingstone, London Bellamy OC, Malcolmson R, Harrison DJ and Wyllie AH (1995) Cell death in health and disease: the biology and regulation of apoptosis Cancer Biology 6 3-16

Billig H, Furuta I and Hsueh AJW (1993) Estrogens inhibit and androgens enhance ovarian granulosa cell apoptosis Endocrinology 133 2204-2211

Bowen ID (1984) Laboratory techniques for demonstrating cell death. In Cell Ageing and Cell Death pp 5-40 Eds I Davies and DC Sigee. Cambridge University Press, Cambridge

Brugal G, Dye R, Krief B, Chassery J-M, Tanke H and Tucker JH (1992) HOME: the highly optimized microscope environment Cytometry 13 109-116

Clarke PGH (1990) Developmental cell death: morphological diversity and multiple mechanisms Anatomical Embryology 181 195-213

Corner GW Jr (1956) The histological dating of the human corpus luteum of menstruation American Journal of Anatomy 98 377-401

Deane HW, Hay MF, Moor RM, Rowson LEA and Short RV (1966) The corpus luteum of the sheep: relationships between morphology and function during the oestrous cycle Acta Endocrinologica 51 245-263

Deghenghi R, Boutignon F, Wuthrich P and Lenaerts V (1993) Antarelix (EP 24332) a novel water soluble LHRH antagonist Biomedicine and Pharmacotherapy 47 107-110

Dharmarajan AM, Goodman SB, Tilly KI and Tilly JL (1994) Apoptosis during functional corpus luteum regression: evidence of a role for chorionic gonadotropin in promoting luteal cell survival Endocrine Journal 2 295-303

Fehrenbach A, Einspanier A, Nicksch E and Hodges JK (1995) Assessment of tissue integrity, ultrastructure and steroidogenic activity of corpora lutea of the marmoset monkey, Callithrix jacchus, following in vitro microdialysis Tissue and Cell 27 467-481

Fraser HM, Abbott M, Laird NC, McNeilly AS, Nestor JJ and Vickery BH (1986) Effects of an LH-releasing hormone antagonist on the secretion of LH, FSH prolactin and ovarian steroids at different stages of the luteal phase in the stumptailed macaque (Macaca arctoides) Journal of Endocrinology $11183-90$

Fraser HM, Lunn SF, Cowen GM and Illingworth PJ (1995) Induced luteal regression in the primate: evidence for apoptosis and changes in c-myc protein Journal of Endocrinology 147 131-137

Gavrieli Y, Sherman Y and Ben-Sasson SA (1992) Identification of programmed cell death in situ via specific labeling of nuclear DNA fragmentation Journal of Cell Biology 119 493-501

Hearn JP, Lunn SF, Burden FJ and Pilcher MM (1975) Management of marmosets for biomedical research Laboratory Animals 9 125-134

Hodges JK, Green DI, Cottingham PG, Sauer MJ, Edwards C and Lightman SL (1988) Induction of luteal regression in the marmoset monkey (Callithrix jacchus) by a gonadotrophin-releasing hormone antagonist and the effects on subsequent follicular development Joumul of Reproduction and Fertility $\mathbf{8 2}$ $743-752$ 
Howie S, Sommerfield A, Gray E and Harrison DJ (1994) Peripheral T lymphocyte deletion by apoptosis after CD4 ligation in vivo: selective loss of CD 44 and 'activating' memory T cells Clinical and Experimental Immunology 95 195-200

Hsueh JW, Billig H and Tsafriri A (1994) Ovarian follicle atresia: a hormonally controlled apoptotic process Endocrine Reviews 15 707-724

Hutchinson JS, NeIson PB and Zeleznik AJ (1986) Effects of different gonadotropin pulse frequencies on corpus luteum function during the menstrual cycle of rhesus monkeys Endocrinology 119 1964-1971

Juengel JL, Garverick HA, Johnson AL, Youngquist RS and Smith MF (1993) Apoptosis during luteal regression in cattle Endocrinology 132 249-254

Kenny N, Williams RE and Kelm LB (1994) Spontaneous apoptosis of cells prepared from the nonregressing corpus luteum Biochemistry and Cell Biology $72531-536$

Kerr JFR, Wyllie AH and Currie AR (1972) Apoptosis: a basic biological phenomenon with wide-ranging implications in tissue kinetics British Journal of Cancer 26 239-257

Morris RG, Duvall E and Wyllie AH (1984) Hormone induced cell death: surface changes in thymocytes undergoing apoptosis American Journal of Pathology 115 426-436

Orlicky DJ, Fisher L, Dunscombe N and Miller GJ (1992) Immunohistochemical localisation of $\mathrm{PGF}_{2 \mathrm{a}}$ receptor in the rat ovary Prostaglandins Leukotrienes and Essential Fatty Acids $46223-229$

O'Shea JD, Nightingale MG and Chamley WA (1977) Changes in small blood vessels during cyclical luteal regression in sheep Biology of Reproduction 17 162-177

Regan RF, Panter SS, Witz A, Tilly IL and Giffard RG (1995) Ultrastructure of excitotoxic neuronal cell death in murine cortical culture Brain Research 705 $188-198$

Rueda BR, Wegner JA, Marion SL, Wahlen DD and Hoyer PA (1995) Internucleosomal DNA fragmentation in ovine luteal tissue associated with in vivo and in vitro analyses Biology of Reproduction 52 305-312

Salazar H, Furr BA, Smith GK, Bentley M and Gonzalez-Angulo A (1976) Luteolytic effects of a prostaglandin analogue, cloprostenol $(\mathrm{ICl} 80,996)$ in rats: ultrastructural and biochemical observations Biology of Reproduction 14 $458-472$

Sawyer HR, Niswender KD, Braden TD and Niswender GD (1990) Nuclear changes in ovine luteal cells in response to $\mathrm{PGF}_{2 a}$ Domestic Animal Endocrinology $7229-238$

Schwartzman RA and Cidlowski JA (1993) Apoptosis: the biochemistry and molecular biology of programmed cell death Endocrine Review 14 133-151

Shikone T, Yamoto M, Kokawa K, Yamashita K, Nishimori K and Nakano R (1996) Apoptosis of human corpora lutea during cyclic luteal regression and early pregnancy Journal of Clinical Endocrinology and Metabolism 81 2376-2380

Smith KB, Lunn SF and Fraser HM (1990) Inhibin secretion during the ovulatory cycle and pregnancy in the common marmoset monkey Journal of Endocrinology 126 489-495

Summers PM, Wennink CJ and Hodges JK (1985) Cloprostenol induced luteolysis in the marmoset monkey (Callithrix jacchus) Journal of Reproduction and Fertility 73 133-138

Tilly JL (1993) Ovarian follicular atresia: a model to study the mechanisms of physiological cell death Endocrine Journal 1 67-72

Trump BF, Berezesky IK and Osornio-Vargas AR (1981) Cell death and the disease process - the role of calcium. In Cell Death in Biology and Pathology pp 209-242 Eds ID Bowen and RA Lockshin. Chapman and Hall, London

Webley GE, Richardson MC, Smith CA, Masson GM and Hearn JP (1990) Size distribution of luteal cells from pregnant and non-pregnant marmoset monkeys and a comparison of the morphology of marmoset luteal cells with those from the human corpus luteum Journal of Reproduction and Fertility 90 427-437

Wyllie AH (1980) Glucocorticoid-induced thymocyte apoptosis is associated with endogenous endonuclease activation Nature 284 555-556

Wyllie AH and Morris RG (1982) Hormone induced cell death: purification and properties of thymocytes undergoing apoptosis after glucocorticoid treatment American Journal of Pathology 109 78-87

Zheng J, Fricke PM, Reynolds LP and Redmer DA (1994) Evaluation of the growth, cell proliferation, and cell death in bovine corpora lutea throughout the estrous cycle Biology of Reproduction 51 623-632 